same time, to intimate the unqualified satis. faction derived from its perusal ;" and, continues he, "To your inquiries, whether we have other objects in view besides medical reform, I shall merely quote the objects stated in the first circular, by which our Association was convened; and though several motions have, since then, been made to engraft scientific and literary purposes upon those mentioned, yet the general voice has been opposed to such measures, and our aims may still, in a succinct manner, be summed up in the following quotation:- The Glasgow Medical Association shall have for its general object to procure a regular and uniform system of medical government, and an equalisation of the privileges of medical practitioners thronghout the empire; and shall have for its peculiar object to cultivate such a union among the unincorporated medical practitioners in Glasgow and its neighbourhood, as may insure to them unanimity and concerted action, agninst all local obstacles to their professional respectability." Then, after giving a few of their laws, Mr. Mackie pro. ceeds :- "The government of our Association may be generally inferred from this sample of its laws, but I may inform you that so urgent appear the evils of the present modes of medical government, of so catholic are the principles of our Association, that those who never uaite for the obtaining of other public measures, admirably harmonise in furtherance of our present ob. jects, as may be readily understood, when you learn that persons of all political parties compose the membership of our Association." And, lastly, the letter continues to say :- "At our first meeting we mean to appoint a Committee for devising some measure of medical reform,-but, for the completion of snch a scheme, and in order that it be well digested; that it embrace all the points necessary in such a measure; that it be adapted to all parts of the empire; that the real wants of the profession be thoroughly understood, and adequately provided for, I know no means so likely as by a convention of delegates from all parts of the three kingdoms. A medical reform bill must be a measure comprehensive, and well pondered ; and to enable all committees to comprebend the proper scope and tendency of such a measure, and the precise course in which their labours should be directed, the hitherto unpublished evidence, taken by $\mathrm{Mr}$. Warburton's Committee, should be early called for."

Letters were also read from Professor Maunsell, of Dublin, and Dr. Cowal, of Reading; the latter in reference to quackery and its abuses.

The election of officers for the ensuing year was then proceded witl.

Resolved unanimously,-_"That Dr. Webster be re-elected to the oftice of President for the ensuing year, being the second year of his election to that office."

The following gentlemen were then elected, by ballot, to fill the offices of Vice-Presidents for the ensuing year.

Dr. Marshall Hall.

Dr. A. B. Granvills.

R. Davidson, Esq.

George Pilcher, Esq.

M. W. Hilles, Esq.

James Howell, Esq.

Resolved unanimously, - "That the other officers be re-elected."

The Council having taken steps for giving publicity to the annual Oration on Medical Reform, as delivered by Dr. A. B. Gran. ville, at the last Anniversary Meeting of the Association, adjourned.

M. F. Wagstaffe,
C.H. Rogers Harrisson, $\}$ Hon. Secs.

\section{SCPPRESSION OF QUACKERY.}

Dr. Cowan has addressed a letter in reply to the letter of Dr. Webster on this subject, in which he states, that "the short outline which he was intending to propose on be. half of the Provincial Association, involved the principal measures contemplated by the British Mindical Association, including the condition of registering the profession, which, if cautiously and strictly done, wonld sare much trouble in legal proced. ings." Dr. Cowan added, "I do not wholly coincide in your opinion, that it would be impolitie to make any separate demands for particular abnases, believing that the ques. tion of non-medical empiricism is of so dis. tinct a nature that it may be safely and suc. cessílly attacked per se, and far more speedily suppressed than if made an item of any plan of general and radical reform. That the latter is much wanted no enlightened man can doubt, but $I$ do not think you will erer obtain it except by degrees, and that introducing any comprehensive measure at once, will in rolve such serions opposing interests that little will be effected. On this principle I have not attempted to interfere expressly with chemists and druggists, not wishing to agitate the question of professional reform in connection with quackery; and $I$ hope on the perusal of the statements I have pre forth that the BrITISH Medical Association will be able to act in concert with the provincial members generally. The objections you mention as com. monly urged by medical men against legislative interference, were precisely the same $I$ have myself encountered, and $I$ have endeavoured to reply to them to the best of my power. I feel confident that Government has no important revenue interest in the question. The whole profits from stamps, patents, advertisements, and wrappers, certainly do not exceed $\$ 50,000$ annually. 
The data are unexceptionable and are detailed. With regard to cordial co-operation, it would give me very sincere pleasure to see both Associations pursuing, hand in hand, any measures which involved the public welfare and professional immunities. (Signed) “Charles Cowan."

\section{SPERIATIC ANIMALCULE OF PLANTS.}

M. Meyer, of Berlin, has recently communicated to the Academy of Sciences the results of his microscupic observations, which demonstrate the existence of spermatic animalculæ in animals. In the year 1836 M. Meyer had mistaken the globules enclosed in the cells of the chara vulgaris, for spermatic animalculæ, but he has since discovered that these globules were nothing more than mucilaginous cells in which the animalcule is formed. When completely detached, and placed in water, the small extremity of the animalcule, which is two or three times longer than the thick end, becomes anterior, and the whole body appears like a thread of mucilage, the movements of which are excessively repid and curious. M. Meyer has examined the animalculæ of seceral species of moss, and promises to communicate the results of his further investigations.-Gez. MIed. ae Paris.

\section{LITHOTRITY IN A CHILD.}

Ir has been asserted, upon high surgical authority in this country, that the operation of lithotrity is not applicable to cases of urinary calculus occurring in the child. The experience of some of the French surgeons is completely opposed to this doctrine.

M. Segalas lattly presented to the Royal Academy of Medicine a boy nearly five years of age, whom he had operated on with success for resical calculus. This child was weakly and affected with rickets, and did not appear to be more than two and a half, or three years of age. He was the oldest child amongst ten, upon M. Segalas had, as yet, operated. The calculus, in this case, was a large one, being an inch and a quarter in diameter. Twelve sittings were required to break it up, and on three different accasions fragments of the stone become arrested in the bladder. Notwith unfavourable circumstances, the boy was completely cured, and in the interval of the sittings was able to run about and play with his companions. On the whole, M. Segalds declares, as the result of his experituce, that whenever the instrument can penetrate to the foreign body, the operation of lithotrity, like that of lithotomy, presents tize more chance of success in prop ortion to the youth of the patient. - Gazette Med. de Paris.

\section{PRIZE REIATIVE TO VACCINATION}

Anongst the notices of the prizes proposed by the Academy of Sciences for the encouragement of medicine, we find one announcing that a prize of 10,000 frants $(£ 400)$ will be awarded in the year 1842, to the best memoir on the following questions :-

Is the preservative power of the vaccine virus permanent, or is it only temporary?

In the latter case determine, by precise experiments and by authentic facts, the time during which its preservatize power continues.

Has the matter of cow-pock, taken from the cow , greater efficacy than the vaccine virus which has been transmitted through several individuals ?

Supposing it to be proved that the eficacy of the vaccine virus is diminished by transmission, should it be renewed, and by what means?

What is the relation between the intensity of the local phenomena, and the preserva. tive power of the vaccine virus?

Is revaccination necessary, and if so, point ont at what period revaccination should be practised?

The amount of the prize proposed by the Academy of Sciences is worthy of the important subject of competition, and does credit to the liberality of that learned body. When will those who labour for the advancement of medical science receive equal encouragement in this country? Were we to judge from the late proceedings at $\mathrm{New}$ castle, we should say after the "Gresk Calends."

\section{RELIEF OF THE SICK POOR.-} CORONER'S INQUEST.

\section{To the Editor of THE LANCET.}

SrR:-The following accident occurred at Warminster, on Thursday, 20th of Aurust last:-

John King, the police constable of Warminster, in attempting to stop a restive and frighted horse, by shutting the turnpikerate, was knocked down, and died about two hours after. I attended him from the time of the accident until the time of his leath, and was particular in noting down : inch circumstances as I expected to be quesliuned on at the coroner's inquest, which $i$., quest was held on the following Saturday, by Mr. Adye, coroner, who, in his address is the jury, said,-"Gentlemen, this acciient lappened in open day, and was witressed by one person here present; it is, therefore, plain lie man came by his death accidentally, and I do not see the necessity to call for evidence of the medical man who 